\title{
Differences in bronchodilating potency of salbutamol in Turbuhaler $\circledast$ as compared with a pressurized metered-dose inhaler formulation in patients with reversible airway obstruction
}

\author{
C-G. Löfdahl*\#, L. Andersson**, E. Bondesson ${ }^{\circ}$, \\ L-G. Carlsson+, K. Friberg ${ }^{\circ}$, J. Hedner*, Y. Hörnblad $¥$, \\ P. Jemsby§, A. Källénº, A. Ullmanº, S. Werner\#, N. Svedmyr*
}

Differences in bronchodilating potency of salbutamol in Turbuhaler ${ }^{\circledR}$ as compared with a pressurized metered-dose inhaler formulation in patients with reversible airway obstruction. C-G. Löfdahl, L. Andersson, E. Bondesson, L-G. Carlsson, K. Friberg, J. Hedner, Y. Hörnblad, P. Jemsby, A. Källén, A. Ullman, S. Werner, N. Svedmyr. OERS Journals Ltd 1997.

ABSTRACT: Two studies are presented, with the aim of establishing the dose potency ratio for salbutamol given via Turbuhaler ${ }^{\circledR}$ and via a pressurized metereddose inhaler (pMDI). Both studies were of a double-blind, randomized design. Outpatients with mild-to-moderate chronic reversible airway obstruction were given single doses of salbutamol administered via Turbuhaler and via pMDI. Efficacy and safety variables were measured before and during $6 \mathrm{~h}$ after each dose.

The first study was a four-way crossover study including 12 patients. The salbutamol doses given were: 50,100 and $2 \times 100 \mu \mathrm{g}$ via Turbuhaler and $2 \times 100 \mu \mathrm{g}$ via pMDI (Ventolin ()$)$. The study showed that $2 \times 100 \mu \mathrm{g}$ of salbutamol inhaled via Turbuhaler is more potent than $2 \times 100 \mu \mathrm{g}$ salbutamol inhaled via a pMDI, and that $100 \mu \mathrm{g}$ salbutamol via Turbuhaler is at least as potent as $2 \times 100 \mu \mathrm{g}$ salbutamol inhaled via a pMDI.

The second study including 50 patients was a placebo-controlled five-way crossover, study. Two doses of salbutamol via Turbuhaler, 50 and $2 \times 100 \mu \mathrm{g}$, and via pMDI, 100 and $2 \times 200 \mu \mathrm{g}$, were given. There was a dose-dependent response in forced expiratory volume in one second (FEV1) for both inhalers. Adjusted for differences in baseline FEV1 values, the estimated relative dose potency for Turbuhaler versus pMDI was 1.98:1 (95\% confidence interval 1.2-3.2).

These studies showed that the same bronchodilating effect can be achieved when half the dose of salbutamol given via a conventional pressurized metered-dose inhaler is given via Turbuhaler.

Eur Respir J 1997; 10: 2474-2478.
*Divisions of Pulmonary Medicine and Clinical Pharmacology, Sahlgrenska University Hospital, University of Göteborg, Sweden. Pulmonary Depts at the hospitals in **Trollhättan, +Uddevalla, $¥$ Malmo and $\S$ Varberg, and the \#Dept of Respiratory Medicine and Allergology, University Hospital, Lund, Sweden. Astra Draco AB, Lund, Sweden.

Correspondence: C-G. Löfdahl

Dept of Respiratory Medicine and Allergology University Hospital

S-221 85 Lund

Sweden.

Keywords: Dry-powder inhaler efficacy

pressurized metered-dose inhaler relative potency

salbutamol

Received: October 301995

Accepted after revision July 251997
The pressurized metered-dose inhaler (pMDI) is the most widely used device for administering inhaled salbutamol, although dry-powder formulations dominate in a few countries. A substantial number of patients do not use their pMDIs optimally, the main problem being difficulties with co-ordination between the actuation of the dose and inhalation [1]. In addition, the chlorofluorocarbons (CFCs) used as propellants and lubricants are suspected of causing bronchoconstriction in some asthmatic individuals $[2,3]$. Furthermore, CFC propellants are harmful to the environment. Restrictions on the use of pMDIs are currently being implemented in several countries.

To overcome co-ordination problems and other drawbacks with pMDIs, inspiratory flow-driven, dry-powder inhalers (DPIs), e.g. Rotahaler ${ }^{\circledR}$ and Diskhaler ${ }^{\circledR}$ (both Glaxo Wellcome Operations, Greenford, Middlesex, UK), have been developed. Turbuhaler® (Astra Pharmaceutical Production AB, Södertalje, Sweden) is an in- spiratory flow-driven multidose DPI [4]. Studies have shown that Turbuhaler deposits a higher fraction of the dose in the lung than do pMDIs or the earlier DPIs [5-9]. Results from a cumulative dose-response study indicated that salbutamol inhaled via Turbuhaler gives better bronchodilating effect than salbutamol inhaled via a pMDI [10].

The aim of the two single-dose studies presented here was to establish the dose potency ratio for salbutamol given via Turbuhaler compared with via a pMDI. In the first study, the lower dose of salbutamol Turbuhaler, $50 \mu \mathrm{g}$, was used for the first time. The relationship between Turbuhaler and pMDI was evaluated using three doses of salbutamol from Turbuhaler and one dose from pMDI. The second study was designed to be a singledose study at two dose levels, that would show dose response for the bronchodilating effect of salbutamol when administered via either inhaler. 


\section{Materials and methods}

\section{Patients}

Study No. 1. Twelve patients, seven males and five females, mean age 50 yrs (range: 24-68) and mean height $175 \mathrm{~cm}$ (range: 161-190) took part in the study. All patients had asthma with an average duration of 10 yrs (range: 3-24). Three patients were current smokers, six former smokers and three had never smoked. The patients had a mean basal forced expiratory volume in one second (FEV1), calculated as the mean of two consecutive measurements, of $2.43 \mathrm{~L}$ (range: 1.42-4.28), i.e. $71 \%$ (range: 46-109) of predicted normal value, and a mean reversibility of FEV1 of $24 \%$ (range: $15-$ 40), 15 min after inhalation of two puffs of salbutamol pMDI (Ventolin $® ;$ Glaxo Wellcome Operations) 100 $\mu \mathrm{g} \cdot$ puff $^{-1}$.

Study No. 2. Fifty patients, 27 males and 23 females, mean age 46 yrs (range: 18-70) and mean height 173 $\mathrm{cm}$ (range: 153-190) took part in the study. All patients had asthma with an average duration of 22 yrs (range: 4-56). Ten patients were current smokers, 18 former smokers and 22 had never smoked. The patients' asthma was characterized by a mean basal FEV1 of $2.22 \mathrm{~L}$ (range: $0.87-4.42$ ), i.e. 65\% pred (range: 35-102), and a mean reversibility of FEV1 of 24\% (range: 15-62), 15 min after inhalation of two puffs of salbutamol pMDI (Ventolin) $100 \mu \mathrm{g} \cdot$ puff $^{-1}$.

All patients gave their signed informed consent. The studies were approved by the Ethics Committees of the universities of Göteborg and Malmö (in the second study only). They were also approved by the Swedish Medical Products Agency and were carried out according to the principles of Good Clinical Practice adopted by the European Community. The studies were performed in accordance with principles stated in the Declaration of Helsinki.

\section{Study design}

The studies were of a randomized, single-dose, crossover and double-blind design. The patients were examined at the same time of day $( \pm 30 \mathrm{~min})$ on nonconsecutive days on which they received a single dose of salbutamol via Turbuhaler, via a pMDI, or placebo (the second study only). In the first study, the salbutamol Turbuhaler doses were 50,100 or $2 \times 100 \mu \mathrm{g}$ and the pMDI dose was $2 \times 100 \mu \mathrm{g}$. In the second study, the Turbuhaler doses were 50 or $2 \times 100 \mu \mathrm{g}$ and the pMDI doses were 100 or $2 \times 200 \mu \mathrm{g}$ salbutamol. Inhaled and nasal glucocorticosteroids, cromolyn sodium, maintenance immunotherapy and acetylcysteine were allowed throughout the study if kept at a constant dosage. Oral and long-acting inhaled $\beta_{2}$-agonists, xanthines and short-acting antihistamines were allowed during the study but were prohibited and washed out before each study day. Xanthines were withdrawn $24 \mathrm{~h}$, oral controlled release $\beta_{2}$-agonists $36 \mathrm{~h}$, and long-acting inhaled $\beta_{2}$-agonists $48 \mathrm{~h}(24 \mathrm{~h}$ in the first study) prior to each study day. Patients were instructed not to inhale short-acting $\beta_{2}$-agonists, ingest caffeine or perform any strenuous activities within $8 \mathrm{~h}$ before performance of study procedures.

\section{Methods}

The technique used for inhalation of study drugs was standardized in accordance with the manufacturers' recommendations. The patients were trained in the correct usage of both inhalers. Training was repeated on the morning of each study day and inhalations were supervised by trained technicians or nurses. Turbuhaler and pMDI were connected one by one in series to a Vitalograph MDI modified Compact spirometer (Vitalograph Ltd, Ennis Co., Clare, Republic of Ireland). By using this technique, peak inspiratory flow (PIF) could be obtained. When patients inhaled salbutamol, a PIF of at least $50 \mathrm{~L} \cdot \mathrm{min}^{-1}$ through Turbuhaler, and approximately $30 \mathrm{~L} \cdot \mathrm{min}^{-1}$ through pMDI was aimed for. Blindness was obtained with a double-dummy technique using placebo for both pMDI and Turbuhaler, which meant that four inhalations in the first study and six inhalations in the second study, had to be performed on each study day. The order in which pMDI and Turbuhaler inhalations were performed was randomized. Active treatment was always given with the first or second inhalation.

Clinical and laboratory assessments were performed before and during $6 \mathrm{~h}$ after study drug administration. Baseline assessments on each study day were performed following a rest of at least $30 \mathrm{~min}$ duration. Lung function measurements, FEV1 and forced vital capacity (FVC), were conducted using a Vitalograph Compact in the first study and a Vitalograph Alpha in the second study (Vitalograph Ltd) and performed according to recommendations by the American Thoracic Society. On each of the study days, baseline FEV1 was not allowed to vary more than $\pm 15 \%$ from FEV 1 at the enrolment visit. If it did vary more, the patient was rescheduled for a new study day (baseline measurement) after 1-7 days. Postdose recordings of FEV1 and FVC were performed at 20,40,60,90,120, 180 (the second study only), 240, 300 (the second study only) and 360 min. Patients were asked for adverse events pre- and at 360 min postdose on each study day.

In the second study, pulse and blood pressure measurements were performed predose and at 20,40,60, $90,120,180,240,300$ and 360 min postdose. A 12-lead electrocardiogram (ECG) and a blood sample for determination of serum potassium concentration were taken predose and at 90 min postdose. The serum potassium concentration was analysed using a direct ion-selective electrode. The patients were asked to grade tremor following a four-point scale predose and at $20 \mathrm{~min}$ postdose. Patient data were entered directly into a computer at the investigational site using the Remote Study Monitoring (RSM) system, a data entry system from Onsite Systems Inc (Augsburg, Germany).

\section{Data analysis}

All patients who had performed more than one study day were included in the analysis. The key pharmacodynamic parameter for lung function measurement data was the average effect (Eav), defined as Area Under the Curve (AUC) of effect versus time divided by observational time $(\sim 6 \mathrm{~h})$. The primary lung function measurement was FEV1. The log-transformed values of 
Eav for FEV1 were analysed with an analysis of variance (ANOVA) model with factors patient, visit and treatment. In the second study, relative dose potency of Turbuhaler versus pMDI and its $95 \%$ confidence interval were also estimated. This was done by fitting parallel lines to the four mean values of $\log E$ av. Mean values for FEV1 are antilogs of those obtained from the ANOVA analysis, and thus adjusted geometric mean values.

In the second study, pulse, blood pressure, the 90 min value of serum potassium and cardiac frequency from the ECG recording were analysed with the same ANOVA model, but without log transformation.

With 12 patients in the first study, a pairwise comparison of two treatments was assumed to give a significant result $(\mathrm{p}<0.05)$ in $80 \%$ of trials provided that the actual mean difference was $90 \%$ of the standard deviation of differences. The choice of 40 evaluable patients in the second study was based on recommendations by the US Food and Drug Administration (FDA) [11]. Differences were considered significant at the $\mathrm{p}<0.05$ level.

\section{Results}

Study No. 1

Inhalation technique. Mean PIFs through Turbuhaler were 60 (range: 44-74), 62 (range: 51-72) and 63 (range: 46-78) $\mathrm{L} \cdot \mathrm{min}^{-1}$, when inhaling 50, 100 and $2 \times 100 \mu \mathrm{g}$ of salbutamol, respectively. When pMDI was studied, mean PIF was 39 (range: 19-71) L· $\mathrm{min}^{-1}$.

FEV1. Mean $( \pm$ SD) basal value for FEV1 was $2.40( \pm 1.03)$, $2.51( \pm 0.97)$ and $2.46( \pm 1.01) \mathrm{L}$, respectively, on the study days with 50,100 and $2 \times 100 \mu \mathrm{g}$ of salbutamol inhaled via Turbuhaler, and $2.40( \pm 0.99) \mathrm{L}$ with $2 \times 100$ $\mu \mathrm{g}$ salbutamol inhaled via pMDI. Corresponding geometric means were $2.22,2.37,2.29$ and 2.15 , respectively.

The FEV1 mean value curves are shown in figure 1.

After correcting for baseline differences (Turbuhaler $100 \mu \mathrm{g}$ ), the FEV1, Eav values, did not differ signifi-

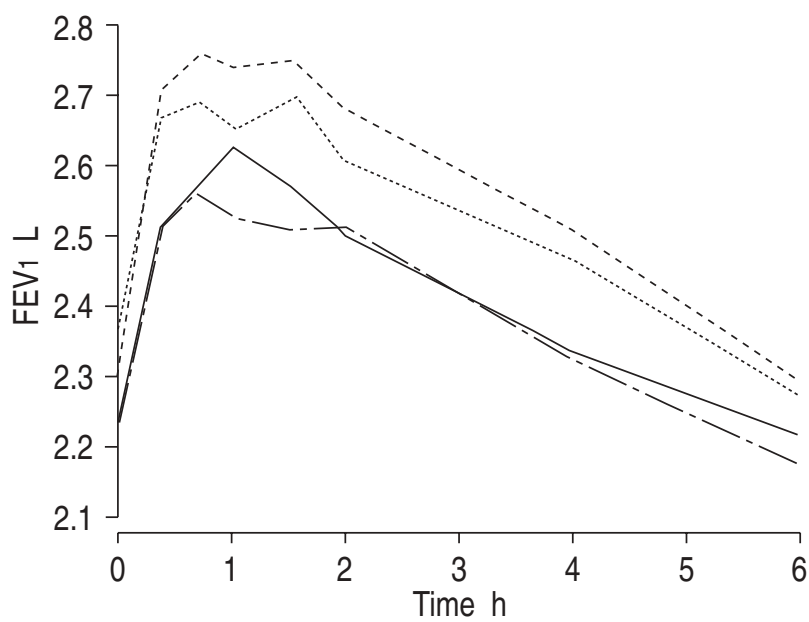

Fig. 1. - Forced expiratory volume in one second (FEV1) mean value curves, study No. 1. - - : salbutamol Turbuhaler (TBH) 50 $\mu \mathrm{g} ;-\ldots . . . . .$. : salbutamol TBH $100 \mu \mathrm{g} ;-.-\ldots$ : salbutamol TBH $2 \times 100$ $\mu \mathrm{g} ;$ — : salbutamol pressurized metered-dose inhaler (pMDI) $2 \times$ $100 \mu \mathrm{g}$. cantly between salbutamol Turbuhaler 50 or $100 \mu \mathrm{g}$ and salbutamol pMDI $2 \times 100 \mu \mathrm{g}$ (table 1$)$. The highest dose inhaled via Turbuhaler, $2 \times 100 \mu \mathrm{g}$, produced a statistically significantly higher response than did $2 \times 100 \mu \mathrm{g}$ inhaled via the pMDI $(\mathrm{p}<0.01)$.

Other variables. No unexpected adverse events were seen with either of the treatments.

\section{Study No. 2}

Inhalation technique. The recorded mean PIF through Turbuhaler was $67 \mathrm{~L} \cdot \mathrm{min}^{-1}$ (range: $40-124$ ) for the 50 $\mu \mathrm{g}$ dose and $66 \mathrm{~L} \cdot \mathrm{min}^{-1}$ (range: 47-97) and $66 \mathrm{~L} \cdot \mathrm{min}^{-1}$ (range: $50-100)$ for the $2 \times 100 \mu \mathrm{g}$ dose. The recorded mean PIF through pMDI was $41 \mathrm{~L} \cdot \mathrm{min}^{-1}$ (range: $10-99$ ) for the $100 \mu \mathrm{g}$ dose and $53 \mathrm{~L} \cdot \mathrm{min}^{-1}$ (range: $25-114$ ) and $48 \mathrm{~L} \cdot \mathrm{min}^{-1}$ (range: $12-90$ ) for the $2 \times 200 \mu \mathrm{g}$ dose.

Each patient's SD for PIF through Turbuhaler and pMDI was calculated for inhalations containing active substance. The mean value of the SDS for PIF was 6.5 $\mathrm{L} \cdot \mathrm{min}^{-1}$ for Turbuhaler and $11.9 \mathrm{~L} \cdot \mathrm{min}^{-1}$ for $\mathrm{pMDI}$. This difference was statistically significant $(p=0.0002)$.

FEV1. Mean basal value for FEV1 was $2.27( \pm 0.96) \mathrm{L}$ before inhalation of placebo, $2.28( \pm 0.92)$ L before Turbuhaler $50 \mu \mathrm{g}, 2.28( \pm 0.95) \mathrm{L}$ before Turbuhaler $2 \times$ $100 \mu \mathrm{g}, 2.22( \pm 0.91) \mathrm{L}$ before pMDI $100 \mu \mathrm{g}$ and 2.23 $( \pm 0.93) \mathrm{L}$ before pMDI $2 \times 200 \mu \mathrm{g}$. Corresponding geometric means were 2.06, 2.09, 2.06, 2.05 and 2.06, respectively.

The FEV1 mean value curves for the active treatments came in two groups, a low and a high dose group (fig. 2). The mean value for Turbuhaler $50 \mu \mathrm{g}$ was slightly higher than for pMDI $100 \mu \mathrm{g}$, but without any significant difference. However, it should be noted that the predose value was somewhat higher for Turbuhaler 50 $\mu \mathrm{g}$ than for the other doses.

An analysis of the FEV1, Eav values showed that all treatments gave a significantly better effect compared with placebo $(\mathrm{p}<0.0001)$ (table 2$)$. The high dose had a better effect than the low dose for both Turbuhaler $(p=0.02)$ and $p M D I(p<0.0001)$. No difference between Turbuhaler and pMDI could be detected, either for the low doses or for the high doses. The coefficient of variation for FEV1, Eav was $5.7 \%$. Relative dose potency of Turbuhaler versus pMDI was estimated adjusting for differences in baseline values. The estimated relative dose potency was 1.98:1 with $95 \%$ confidence interval

Table 1. - Average effect (FEV 1$)$ comparison between treatments, study No. 1

\begin{tabular}{lrrc}
\hline Comparison & $\begin{array}{c}\text { Ratio } \\
\%\end{array}$ & $95 \%$ CI & p-value \\
\hline TBH 50 $\mu \mathrm{g} / \mathrm{pMDI} 2 \times 100 \mu \mathrm{g}$ & 99.2 & $95.2-103.3$ & $\mathrm{NS}$ \\
TBH 100 $\mu \mathrm{g} / \mathrm{pMDI} 2 \times 100 \mu \mathrm{g}$ & 104.7 & $100.5-109.0$ & 0.03 \\
TBH 2 $\times 100 \mu \mathrm{g} / \mathrm{pMDI} 2 \times 100 \mu \mathrm{g}$ & 106.4 & $102.1-110.9$ & 0.004 \\
Baseline adjusted TBH & & & \\
$100 \mu \mathrm{g} / \mathrm{pMDI} 2 \times 100 \mu \mathrm{g}^{+}$ & 101.4 & $97.6-105.3$ & NS \\
\hline
\end{tabular}

95\% CI: 95\% confidence interval. ${ }^{+}$: adjusted for the higher baseline value for Turbuhaler $100 \mu \mathrm{g}$. Ns: nonsignificant; TBH: Turbuhaler; pMDI: pressurized metered-dose inhaler; FEV1: forced expiratory volume in one second. 


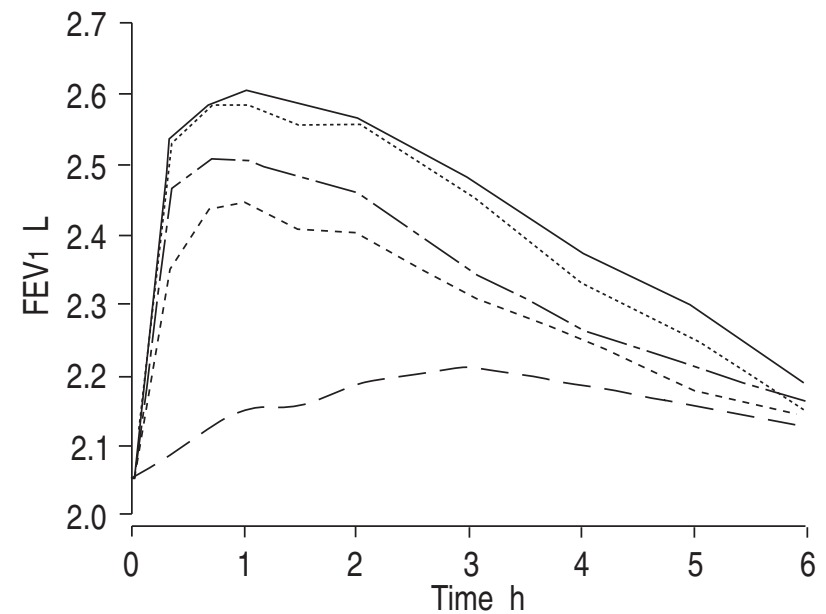

Fig. 2. - FEV1 mean value curves, study no. 2. - - - : salbutamol

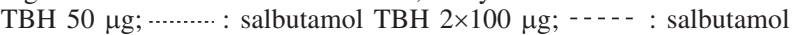
pMDI $100 \mu \mathrm{g} ;-\longrightarrow$ : salbutamol pMDI $2 \times 200 \mu \mathrm{g} ;--$ : placebo. For definitions, see legend to figure 1.

Table 2. - Average effect (FEV 1$)$ comparison between treatments, study No. 2

\begin{tabular}{|c|c|c|c|}
\hline Comparison & $\begin{array}{c}\text { Ratio } \\
\%\end{array}$ & $95 \% \mathrm{CI}$ & p-value \\
\hline pMDI $100 \mu \mathrm{g} /$ placebo & 106.2 & $103.8-108.6$ & $<0.0001$ \\
\hline TBH $50 \mu \mathrm{g} / \mathrm{pMDI} 100 \mu \mathrm{g}$ & 102.0 & $99.7-104.3$ & NS \\
\hline TBH $2 \times 100 \mu \mathrm{g} / \mathrm{pMDI} 2 \times 200 \mu \mathrm{g}$ & 99.0 & $96.8-101.3$ & NS \\
\hline ТВН $2 \times 100 \mu \mathrm{g} / \mathrm{TBH} 50 \mu \mathrm{g}$ & 102.8 & $100.5-105.2$ & 0.02 \\
\hline $\begin{array}{l}\text { pMDI } 2 \times 200 \mu \mathrm{g} / \mathrm{pMDI} 100 \mu \mathrm{g} \\
\text { Baseline adjusted TBH }\end{array}$ & 105.9 & $103.6-108.3$ & $<0.0001$ \\
\hline $50 \mu \mathrm{g} / \mathrm{pMDI} 100 \mu \mathrm{g}^{+}$ & 101.0 & 98.9-103.1 & NS \\
\hline
\end{tabular}

+ : adjusted for the higher baseline value for Turbuhaler $50 \mu \mathrm{g}$. For definitions see legend to table 1 .

1.2-3.2 (fig. 3). Without the adjustment, the potency ratio was $2.36: 1$.

The number of patients responding with at least a $15 \%$ increase in FEV1 at 40 min after dosing was 3, 32, 44, 30 and 44 for placebo, Turbuhaler $50 \mu \mathrm{g}$, Turbuhaler $2 \times 100 \mu \mathrm{g}$, pMDI $100 \mu \mathrm{g}$ and pMDI $2 \times 200 \mu \mathrm{g}$, respectively. Forty minutes was judged to be a relevant timepoint by which a short-acting $\beta_{2}$-agonist should have executed a substantial improvement in lung function.

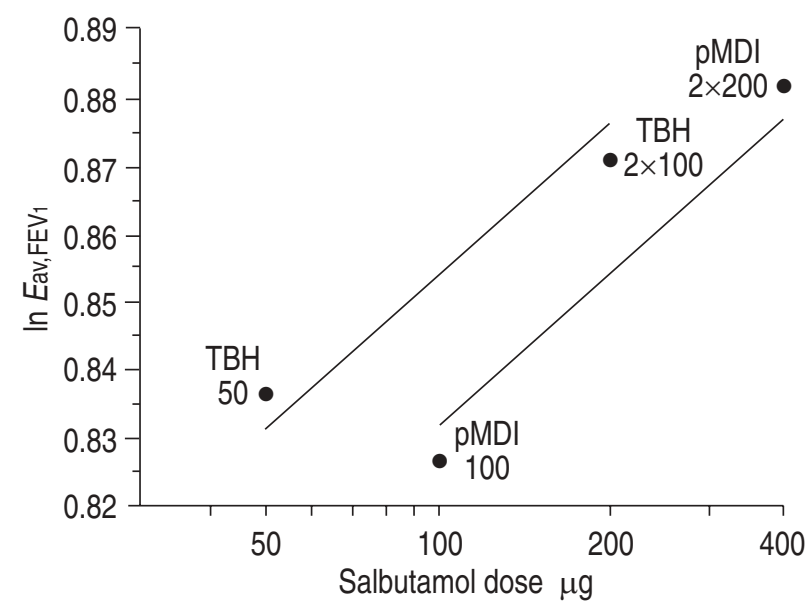

Fig. 3. - Relative dose potency of salbutamol administered via Turbuhaler and via pMDI, study No. 2. Eav: average effect; ln: natural logarithm. For further definitions, see legend to figure 1.
Table 3. - Mean and minimum serum potassium values at baseline and $90 \mathrm{~min}$ after dose, study No. 2

\begin{tabular}{|c|c|c|c|c|}
\hline \multirow{3}{*}{ Treatment } & \multicolumn{4}{|c|}{ Serum potassium $\mathrm{mmol} \cdot \mathrm{L}^{-1}$} \\
\hline & \multicolumn{2}{|c|}{ Mean } & \multicolumn{2}{|c|}{ Minimum } \\
\hline & Baseline & $90 \min$ & Baseline & $90 \mathrm{~min}$ \\
\hline Placebo & 4.33 & 4.57 & 3.8 & 4.0 \\
\hline TBH $50 \mu \mathrm{g}$ & 4.38 & 4.53 & 3.9 & 3.7 \\
\hline TBH $2 \times 100 \mu \mathrm{g}$ & 4.36 & 4.48 & 3.8 & 3.9 \\
\hline pMDI $100 \mu \mathrm{g}$ & 4.41 & 4.54 & 3.9 & 3.8 \\
\hline pMDI $2 \times 200 \mu \mathrm{g}$ & 4.34 & 4.46 & 3.9 & 4.0 \\
\hline
\end{tabular}

For definitions, see legend to table 1 .

Table 4. - Mean and maximum change in cardiac frequency from baseline to $90 \mathrm{~min}$ after dose, study No. 2

\begin{tabular}{lcc}
\hline Treatment & $\begin{array}{c}\text { Cardiac frequency } \\
\text { mean change } \\
\text { bpm }\end{array}$ & Maximum change \\
\hline Placebo & -4 & bpm \\
TBH 50 $\mu \mathrm{g}$ & -6 & 35 \\
TBH 2 $\times 100 \mu \mathrm{g}$ & -4 & 7 \\
pMDI 100 $\mu \mathrm{g}$ & -6 & 1 \\
pMDI 2 $200 \mu \mathrm{g}$ & -6 & 7 \\
\hline
\end{tabular}

bpm: beats per minute. For further definitions, see legend to table 1.

Serum Potassium. Potassium was little affected by the treatments. In comparison with placebo, the only statistically significant effect was seen with the highest pMDI dose $(\mathrm{p}=0.01)$. Arithmetic mean and minimum values at baseline and at $90 \mathrm{~min}$ after dose are presented in table 3 .

Tremor. A total of 14 positive scores (score $1=$ mild) was given by eight different patients. Only on eight of these 14 occasions was tremor reported after dose administration, four occasions concerned placebo treatment, one Turbuhaler $50 \mu \mathrm{g}$, one Turbuhaler $2 \times 100 \mu \mathrm{g}$ and two pMDI $2 \times 200 \mu \mathrm{g}$.

Other safety variables. No treatment effect could be demonstrated on $E$ av for pulse and blood pressure or on the mean change in cardiac frequency counted from ECG. Mean and maximum changes from baseline to 90 min after dose in cardiac frequency and blood pressure are presented in table 4 . There were no other relevant pathological ECG findings.

No unexpected adverse events were seen with either of the treatments.

\section{Discussion}

The present studies showed an approximate mean 2:1 dose potency ratio for salbutamol given via Turbuhaler as compared with salbutamol given via pMDI.

The ideal comparison of dose-response curves is performed on the steep part of the curve. A problem is that the doses given with the currently used $\beta_{2}$-agonist inhalation devices often give an almost maximum effect when given as single doses.

In the first study, which was performed after a cumulative dose-response study indicating a higher dose potency ratio for salbutamol Turbuhaler in comparison 
with the pMDI [10], three doses were given with Turbuhaler and one with pMDI.

In the second study, the lowest possible dose with each equipment was given together with a fourfold higher dose. These doses showed a dose-response relationship for bronchodilation of salbutamol inhaled via either of the inhalers.

In the second study, the highest dose of each equipment may be at the top of the dose-response curve, in which case these mean values can not be used as an argument for the 1.98:1 ratio. However, the similar mean values on the lower part of the curve, i.e. $50 \mu \mathrm{g}$ salbutamol via Turbuhaler and $100 \mu \mathrm{g}$ via pMDI favour a 1.98:1 ratio. The $95 \%$ confidence interval for this ratio was $1.2-3.2$.

Clearly, an effective inhalation technique is mandatory for optimum delivery of inhaled study drug. Specific training sessions were therefore undertaken in these studies. Inhalations were supervised and actual airflow was monitored. The mean PIF through Turbuhaler was about $60 \mathrm{~L} \cdot \mathrm{min}^{-1}$, which represents a typical inhalation flow through Turbuhaler for asthmatic patients $[12,13]$. At a lower inhalation flow of around $30 \mathrm{~L} \cdot \mathrm{min}^{-1}$, the fraction delivered to the patient is decreased, but it has been shown that some efficacy is still maintained [14, 15]. In the second study, when PIF data was analysed, it was seen that patients had some difficulty in performing a slow inhalation, which is optimal with the pMDI [16]; the mean inspiratory flow was $47 \mathrm{~L} \cdot \mathrm{min}^{-1}$. This is also indicated in the same study by the PIF values being more widely spread for inhalation via pMDI than via Turbuhaler.

The 1.98:1 dose potency ratio is well in accordance with lung deposition data from studies performed with other substances. The ratio for terbutaline administered via Turbuhaler and via pMDI was 2:1 both for bronchodilating potency and lung deposition [8]. For budesonide, the lung deposition was also twice as high with Turbuhaler than with pMDI [7]. Data also indicate that patients may be controlled by half the dose when switched from pMDI to Turbuhaler formulations of budesonide [17].

The present studies did not show any important sign of systemic drug effect and there was no difference between inhalers. This is well in accordance with the previous cumulative dose-response study (maximum total dose $1600 \mu \mathrm{g}$ ) which did not show any difference in side-effects when comparing salbutamol Turbuhaler and pMDI at equal bronchodilating effect [10].

In conclusion, these studies showed that the same bronchodilating effect can be achieved when half the dose of salbutamol given via a conventional pressurized metered-dose inhaler is given via Turbuhaler.

Acknowledgement: We would like to acknowledge M. Ljunggren, and J. Rosenborg for their assistance with the studies.

\section{References}

1. Crompton GK. Problems patients have using pressurized aerosol inhalers. Eur J Respir Dis 1982; 63: Suppl. $119,101-104$.
2. Engel T, Heinig JH, Malling HJ, Scharling B, Nikander $\mathrm{K}$, Madsen F. Clinical comparison of inhaled budesonide delivered either via pressurized metered dose inhaler or Turbuhaler®. Allergy 1989; 44: 220-225.

3. Jackson L, Ståhl E, Holgate ST. Terbutaline via pressurized metered dose inhaler (P-MDI) and Turbuhaler ${ }^{\circledR}$ in highly reactive asthmatic patients. Eur Respir J 1994; 7: 1598-1601.

4. Wetterlin K. Turbuhaler: A new powder inhaler for administration of drugs to the airways. Pharm Res 1988; 5(8): 506-508.

5. Melchor R, Biddiscombe MF, Mak VHF, Short MD, Spiro SG. Lung deposition patterns of directly labelled salbutamol in normal subjects and in patients with reversible airflow obstruction. Thorax 1993; 48: 506-511.

6. Borgström L, Newman S. Total and regional lung deposition of terbutaline sulphate inhaled via a pressurized MDI or via Turbuhaler®. Int J Pharm 1993; 97: 47-53.

7. Thorsson L, Edsbäcker S. Lung deposition of budesonide from Turbuhaler is twice that from a pressurized metered dose inhaler (MDI). (Abstract). Thorax 1993; 48: 434.

8. Borgström L, Derom E, Ståhl E, Wåhlin-Boll E, Pauwels R. Inhalation device influences lung deposition and bronchodilating effect of terbutaline. Am J Respir Crit Care Med 1996; 153: 1636-1640.

9. Borgström L. Methodological studies on lung deposition. Evaluation of inhalation devices and absorption mechanisms. Acta Univ Ups Comprehensive Summaries of Uppsala Dissertations from the Faculty of Pharmacy 105, 1993.

10. Löfdahl C-G, Arvidsson P, Bondesson E, Friberg K. Higher potency of salbutamol when given via Turbuhaler ${ }^{\circledR}$ than via pressurized metered dose inhaler (pMDI). In: Abstracts from XV International Congress of Allergology and Clinical Immunology (ICACI) and Annual Meeting of the European Academy of Allergology and Clinical Immunology (EAACI), Stockholm. (Abstract). Allergy Clin Immunol News 1994; 6 (Suppl. 2): 383.

11. Division of Bioequivalence, the Centre for Drug Evaluation and Research/the Food and Drug Administration. Guidance for In-Vivo Bioequivalence Studies of Metaproterenol Sulfate and Salbutamol Inhalation Aerosols (Metered Dose Inhalers). 21 Code of Federal Register (CFR) 10.90.

12. Engel T, Heinig JH, Madsen F, Weeke B, Nikander K. Peak inspiratory flow and inspiratory vital capacity of patients with asthma measured with and without a new dry-powder inhaler device (Turbuhaler®). Eur Respir J 1990; 3: 1037-1041.

13. Brown PH, Greening AP, Crompton GK. Peak inspiratory flow rate in acute asthma: are they adequate for efficient use of a Turbohaler? (Abstract). Thorax 1992; 47: 239P.

14. Engel T, Scharling B, Skovsted B, Heinig JH. Effects, side effects and plasma concentrations of terbutaline in adult asthmatics after inhaling from a dry powder inhaler device at different inhalation flows and volumes. $\mathrm{Br} J$ Clin Pharmacol 1992; 33: 439-444.

15. Pedersen S, Hansen OR, Fuglsang G. Influence of inspiratory flow rate upon the effect of a Turbuhaler. Arch Dis Child 1990; 65: 308-310.

16. Newman SP, Pavia D, Clarke SW. Improving the bronchial deposition of pressurized aerosols. Chest 1981; 80 (No. 6 Suppl.): 909-911.

17. Agertoft L, Pedersen S. Importance of the inhalation device on the effect of budesonide. Arch Dis Child 1993; 69: 130-133. 